\title{
A LEI DE IMPROBIDADE E A PROIBIÇÃO DE RECEBER BENEFÍCIOS FISCAIS OU CREDITÍCIOS
}

\section{THE "STATUTE OF IMPROBITY" AND PROHIBITION OF RECEIVING FISCAL OR CREDIT BENEFITS}

Carlos Ari Sundfeld ${ }^{1}$

Rodrigo Pagani de Souza ${ }^{2}$

RESUMO: O artigo analisa, à luz da jurisprudência do Superior Tribunal de Justiça, qual deve ser a abrangência objetiva e subjetiva da sanção de proibição de "receber benefícios ou incentivos fiscais ou creditícios, direta ou indiretamente, ainda que por intermédio de pessoa jurídica da qual seja sócio majoritário ...” (art. 12, I, II e III da lei 8.429, de 1992).

PALAVRAS-CHAVE: Improbidade. Benefícios fiscais ou creditícios. Proporcionalidade. Desconsideração da personalidade jurídica.

ABSTRACT: The article analyses, considering the Superior Court of Justice (STJ) jurisprudence, what shall be the comprehensiveness of the sanction of prohibition of "receiving fiscal or credit benefits and incentives, direct or indirectly, even if the act of receiving develops through the legal entity of which one is a majority shareholder..." (article 12, I, II e III of Statute n. 8.429, of 1992).

KEYWORDS: Improbity. Fiscal and credit benefits. Proportionality. Disregard of the corporate form.

\section{INTRODUÇÃO}

O objetivo deste estudo ${ }^{3}$ é discutir, inclusive à luz da evolução jurisprudencial do Superior Tribunal de Justiça (STJ), quais podem ser os efeitos de decisão judicial que, em

\footnotetext{
${ }^{1}$ Professor Titular da FGV Direito SP, Doutor e Mestre em Direito pela PUC/SP e Presidente da Sociedade Brasileira de Direito Público - SBDP. Email: carlos.sundfeld@ fgv.br

${ }^{2}$ Professor da Faculdade de Direito da USP, Doutor e Mestre pela mesma instituição e Master of Laws pela Universidade de Yale. Email: rodrigo.pagani@usp.br
} 
ação de improbidade administrativa (lei 8.429, de 2 de junho de 1992), pretenda impor a proibição de "receber benefícios ou incentivos fiscais ou creditícios, direta ou indiretamente, ainda que por intermédio de pessoa jurídica da qual seja sócio majoritário ...” (art. 12, I, II e III)".

O tema se insere em tópico mais amplo, o da aplicação das inúmeras sanções que, na Lei de Improbidade, foram previstas de modo muito abstrato e aberto - problema que o Superior Tribunal tem procurado enfrentar exigindo com ênfase o respeito ao dever de proporcionalidade. A jurisprudência ainda não se estabilizou e os julgados variam muito em função dos elementos de cada caso, mas tem havido neles um sentido comum: a preocupação com a pertinência da sanção em face da infração efetivamente constatada.

Essa preocupação tem feito inclusive com que o STJ abrande na prática o rigor de sua Súmula $\mathrm{n}^{\circ} 7$ e, apesar de seu consolidado posicionamento de que a revisão da dosimetria das sanções implicaria o reexame do conjunto fático-probatório dos autos, permita-se rever a dosimetria adotada em certos casos, "modulando" assim em concreto os efeitos da condenação por improbidade.

Nalguns casos, por exemplo, tem reconhecido a inobservância dos limites estabelecidos no art. 12 da Lei 8.429/92 e afastado os excessos de condenações impostas por instâncias inferiores. ${ }^{4}$ Noutros, tem mantido as decisões dos tribunais inferiores que reduzem condenações por improbidade para adequá-las a padrões de proporcionalidade e razoabilidade. ${ }^{5}$ Seja pelo ângulo da coibição dos excessos da pena, seja pelo da manutenção

\footnotetext{
${ }^{3}$ Os autores agradecem a excelente colaboração da professora Vera Monteiro, da FGV Direito SP, e do advogado Liandro Domingos, na pesquisa que serviu de base a este trabalho e na discussão de seus resultados.

${ }^{4}$ Neste sentido, com o fundamento da proporcionalidade e da razoabilidade, o STJ excluiu parte das sanções impostas em caso concreto, mantendo somente as que entendeu suficientes para a repressão e penalização pelos atos de improbidade verificados. Assinalou: "Destarte, revela-se necessária a observância da lesividade e reprovabilidade da conduta do agente, do elemento volitivo da conduta e da consecução do interesse público, para efetivar a dosimetria da sanção por ato de improbidade, adequando-a à finalidade da norma. In casu, a desproporcionalidade das penas de perda da função pública e suspensão de direitos políticos por 8 (oito) anos, aplicadas ao condenado, é manifesta, mercê de evidente a desobediência ao princípio da razoabilidade, circunstância que, por si só, viola o disposto no art. 12, parágrafo único da Lei 8.429/92, verificável independentemente da análise de fatos e provas constantes dos autos. Recurso Especial parcialmente provido, para que sejam excluídas da condenação do ora recorrente as penas de perda da função pública e suspensão de direitos políticos por 8 (oito) anos, nos termos da fundamentação". STJ, REsp 1.130198-RR, rel. Ministro LUIZ FUX, Primeira Turma, j. em 2.12.2010, DJe 15.12.2010.

${ }^{5}$ Mantendo acórdão do TJSP que minimizou as sanções impostas pela sentença de $1^{\circ}$ grau, o STJ concluiu pela conformidade das penas aplicadas: "A jurisprudência do STJ é no sentido de que a aplicação das penalidades previstas no art. 12 da Lei 8.429/1992 exige que o magistrado considere, no caso concreto, 'a extensão do dano causado, assim como o proveito patrimonial obtido pelo agente' (conforme previsão expressa contida no parágrafo único do referido artigo). Assim, é preciso analisar a razoabilidade e a proporcionalidade em relação à gravidade do ato ímprobo e à cominação das penalidades, as quais podem ocorrer de maneira cumulativa ou não.
} 
de decisões comedidas, o movimento dessa jurisprudência paulatinamente construída pelo STJ tem sido o de exigir adequada calibração entre penalidade e infração.

O STJ já assentou orientações jurisprudenciais: reconhecendo que as sanções previstas no art. 12 não se aplicam, necessariamente, de maneira cumulativa; ${ }^{6}$ circunscrevendo a aplicabilidade de penas restritivas ao âmbito de determinado ente da federação ou, até mesmo, de entidade de sua administração indireta; ${ }^{7}$ e, claro, demandando motivação explícita e adequada para cada pena aplicada. ${ }^{8}$ É, portanto, claro e seguro o percurso do STJ no sentido de exigir perfeita calibração entre a sanção e o ato de improbidade efetivamente apurado.

Interessa, então, ao presente estudo, verificar o que essa diretriz jurisprudencial tem a dizer sobre as diversas dúvidas possíveis especificamente quanto à abrangência dos efeitos da proibição de receber benefícios ou incentivos fiscais ou creditícios.

\footnotetext{
5. Hipótese em que o Tribunal de origem, com base neste conjunto fático-probatório bem delimitado, minimizou as sanções aplicadas na sentença, alegando ser desnecessária a cumulação de todas as penas nos termos do art. 12, III, da Lei 8.429/1992. As penalidades ficaram assim dispostas: 'é de permanecer tão-só a multa civil, cancelando-se todas as demais sanções.' 6. Não há falar em violação à Lei 8.429/1992, por estar o acórdão recorrido em conformidade com os princípios da razoabilidade e da proporcionalidade". STJ, AgRg no REsp 1.242.939 SP, rel. Ministro HERMAN BENJAMIN, Segunda Turma, j. em 24.5.2011, DJe 30.5.2011.

${ }^{6}$ Por exemplo, neste julgado: "As sanções do art. 12, incisos I, II e III, da Lei $\mathrm{n}^{\circ}$ 8.429/92, não são necessariamente cumulativas, cabendo ao magistrado a sua dosimetria, em consonância com os princípios da razoabilidade e da proporcionalidade, que, evidentemente, perpassa pela adequação, necessidade e proporcionalidade estrito senso, aliás, como deixa entrever o parágrafo único do referido dispositivo, a fim de que a reprimenda a ser aplicada ao agente ímprobo seja suficiente à repressão e à prevenção da improbidade". STJ, REsp 980.706-RS, rel. Ministro LUIZ FUX, Primeira Turma, j. em 3.2.2011, DJe 23.2.2011.

${ }^{7}$ Como no caso da contratação das empreiteiras pela LIMPURB - STJ, EDcl no REsp n. ${ }^{\circ}$ 1.021.851-SP, rel. Ministra ELIANA CALMON, Segunda Turma, j. em 23.6.2009, DJe de 6.8.2009.

${ }^{8}$ O STJ já declarou a nulidade de acórdão que deixou de fornecer a indispensável fundamentação para a aplicação das sanções previstas no art. 12, da LIA: "Havendo, na Lei 8.492/92 (Lei de Improbidade Administrativa), a previsão de sanções que podem ser aplicadas alternativa ou cumulativamente e em dosagens variadas, é indispensável, sob pena de nulidade, que a sentença indique as razões para a aplicação de cada uma delas, levando em consideração o princípio da razoabilidade e tendo em conta 'a extensão do dano causado assim como o proveito patrimonial obtido pelo agente' (art. 12, parágrafo único).

(...) $\mathrm{O}$ artigo 12 da Lei 8.492/92 (Lei de Improbidade Administrativa), traz previsão de um elenco variado de sanções, que podem ser aplicadas alternativa ou cumulativamente e com dosagens variáveis. Segundo dispõe o parágrafo único do artigo, "na fixação das penas previstas nesta lei o juiz levará em conta a extensão do dano causado assim como o proveito patrimonial obtido pelo agente". É indispensável, portanto, que, a exemplo do que ocorre no processo penal, haja aqui a individuação da pena, com a indicação dos fundamentos e das razões para a aplicação de cada uma delas. A devida fundamentação é requisito essencial da sentença (CPC, art. 458, II) e compõe o devido processo legal constitucional, pois é ela que ensejará ao sancionado o exercício do direito de defesa e de recurso (CF, art. $5^{\circ}$, LIV e LV). A ausência desse requisito acarreta a nulidade da decisão (CF, art. 93, IX)". STJ, REsp 507.574-MG, rel. Ministro TEORI ZAVASCHI, Primeira Turma, j. em 15.9.2005, DJe 8.5.2006.
} 
A primeira dúvida é de ordem objetiva, quanto aos benefícios e incentivos alcançados pela sanção: é correto que a sentença proíba em bloco o recebimento de todo e qualquer benefício e incentivo, independentemente de sua natureza, fundamento ou setor?

A segunda dúvida é de ordem subjetiva, isto é, quanto à necessidade ou não de existir coincidência entre a entidade estatal prejudicada pelo ato de improbidade e a entidade competente para a concessão do benefício ou incentivo que se vai suprimir a título de sanção. É correto que, para punir a falta cometida contra certa entidade estatal (um Município, por exemplo) a Justiça proíba a fruição de incentivo ou benefício oriundo de quaisquer outras entidades estatais do Brasil (a União e cada um dos Estados e Municípios, além das respectivas administrações indiretas)?

A terceira dúvida é também de ordem subjetiva, mas agora com relação ao sujeito alcançado pela punição: o fato de a lei descrever a sanção como uma proibição de receber benefício ou incentivo "ainda que por intermédio de pessoa jurídica da qual seja sócio majoritário" (art. 12, I, II e III) significa que esta sanção alcança sempre e automaticamente todas as pessoas jurídicas de que o punido seja sócio majoritário, direta ou indiretamente?

São estas, portanto, as dúvidas a serem discutidas aqui.

\section{1. É ILEGAL A SANÇÃO DE SUPRESSÃO EM BLOCO DE TODOS OS BENEFÍCIOS E INCENTIVOS FISCAIS OU CREDITÍCIOS EXISTENTES NO PAÍS}

Passando ao desafio de compreensão quanto à penalidade de proibição de "receber benefícios ou incentivos fiscais ou creditícios" do Poder Público, cumpre relembrar que se trata da aplicação de sanção pela prática de certa infração perfeitamente especificada (ato de improbidade). Imprescindível, pois, que haja conexão entre o conteúdo da sanção e o conteúdo da infração. Esta relação de conexão entre infração e sanção é, como se disse, requerida pela regra de proporcionalidade, essencial em direito sancionador.

É de se notar que a terminologia da lei inspira-se em linguagem semelhante encontrada no art. $195, \S 3^{\circ}$, da Constituição Federal (“A pessoa jurídica em débito com o sistema da seguridade social, como estabelecido em lei, não poderá contratar com o Poder Público nem dele receber benefícios ou incentivos fiscais ou creditícios").

Todavia, seria um equívoco confundir esta norma constitucional com aquela que acabou instituída na Lei de Improbidade. A Constituição prevê simples causa transitória e 
superável de impedimento para a contratação com o Poder Público ou obtenção de benefícios do gênero; é um incentivo ao adimplemento de obrigações tributárias; quitado o débito, a entidade volta imediatamente a contratar ou obter os tais benefícios.

Já a norma da Lei de Improbidade institui sanção duradoura pela prática de ilícito, a ser aplicada pelo juiz, e que se estende no espaço e no tempo, sem que a ação do apenado possa suspendê-la. Tal aplicação de sanção deve, por óbvio, ser ajustada às normas atinentes ao direito sancionador. Além de haver relação de pertinência lógica entre a infração e a pena, deve ainda existir proporcionalidade entre uma e outra, bem como ser individualizada a pena e respeitada a incomunicabilidade das sanções.

A proporcionalidade não significa apenas uma relação adequada entre infração e sanção em termos de gravidade (p.ex., infração leve há de resultar em pena leve, infração grave em pena grave); significa também adequação em termos de conexão ou pertinência lógica entre uma e outra, levando-se em conta distintos aspectos da infração cometida no caso concreto. Aspectos a serem considerados na imposição e dosimetria de sanções por improbidade estão previstos no parágrafo único do seu art. 12 - quais sejam, a "extensão do dano causado" (em termos de sujeito, território, patrimônio ou interesse público atingidos, p.ex.) e o "proveito patrimonial obtido pelo agente" (em termos de bens e valores, p.ex.).

Em harmonia com a citada diretriz de "calibração da sanção à infração", a qual vem sendo constantemente adotada pelo Superior Tribunal de Justiça, parece correto afirmar, embora não se tenha notícia de a questão já ter sido apresentada ao tribunal, que cabe ao juiz, na sentença de condenação por improbidade, especificar exatamente quais os benefícios $e$ incentivos fiscais ou creditícios cuja obtenção deve ser sonegada ao apenado. Afinal, a previsão legal de reprimenda com "proibição de (...) receber benefícios ou incentivos físcais ou creditícios" ainda requer, para ser consistentemente aplicada, um exercício de dosimetria pelo juiz, a ser feito em função de sua análise da infração (ato ímprobo) concretamente verificada.

Há que fazer a subsunção do caso à hipótese legal, para, somente então, surpreendido e comprovado o ato de improbidade nas suas circunstâncias concretas, calibrar qual será a extensão da reprimenda. Cumpre ao julgador fazer um exercício de cognição profunda dos fatos que julga, para então especificar e dosar a pena. ${ }^{9}$

\footnotetext{
${ }^{9}$ Como já decidiu o Tribunal de Justiça do Estado do Rio Grande do Sul (TJRS): “...ao quantificar a culpa do agente é que, conjugado com os demais operadores fáticos colaterais ao fato-ímprobo, o julgador poderá aferir
} 
Em suma, somente a subsunção dos fatos à norma é que possibilita ao juiz estipular adequadamente a sanção para o caso concreto. Aí então lhe cabe, em sendo o caso de vedar o acesso do apenado a certos benefícios e incentivos fiscais ou creditícios outorgáveis pelo Poder Público, dizer quais deles ficam temporariamente vedados.

Esta especificação da pena de proibição de receber tais benefícios ou incentivos é fundamental para calibrá-la com a infração, inclusive com o propósito de desestimular o apenado a reincidir no ato ímprobo. Assim, àquele que tenha praticado improbidade no âmbito de atividades relacionadas ao agronegócio cabe verificar a pertinência, p.ex., de vedarlhe temporariamente o acesso a benefícios ou incentivos estatais relacionados ao tema. Àquele que tenha praticado improbidade no âmbito da exportação de bens e serviços caberia estudar a pertinência, p.ex., de proibir temporariamente o acesso a incentivos à exportação.

Mas não é viável que se proíba o acesso a todos estes benefícios e incentivos públicos quando, em realidade, nem o ato de improbidade concretamente verificado, nem o ramo de atuação do apenado, nem qualquer circunstância do caso analisado guardem relação de pertinência com tal proibição. Aliás, o STJ já decidiu que a proibição de receber benefícios ou incentivos fiscais ou creditícios requer demonstração de que o réu tenha estrita relação com esses tipos de atividade (da mesma forma, a imposição da pena de suspensão de direitos políticos, segundo entendeu o STJ na mesma ocasião, requer que os atos de improbidade praticados tenham revelado algum cunho político). ${ }^{10}$

sobre este sancionamento. O julgador não deve e não pode aplicar a lei de modo formal sem fazer uma análise crítica de seu conteúdo e dos fatos aos quais fará incidir a norma. Necessário ao aplicar a norma que o julgador faça um exercício de cognição profunda dos fatos que julga, em sua integralidade”. TJRS, Apelação Cível 70033461856, rel. Desembargador Jorge Maraschin dos Santos, j. em 15.12.2010.

${ }^{10}$ Cuidava-se de caso em que o Tribunal de Justiça do Estado do Paraná (TJPR) apresentara, especificamente, as justificativas que o haviam levado a aplicar somente a pena de perda da função pública a escrivão de polícia que efetuara apreensão de veículo sem lavrar o respectivo auto de apreensão e, sem comunicar a autoridade competente, passou a utilizá-lo para fins pessoais. O STJ manteve a decisão do tribunal local, bem como a sua fundamentação, que interessa aqui expor:

"Na espécie em tela, o ato ímprobo não trouxe grande prejuízo ao erário (a não lavratura do auto de busca e apreensão e o uso de um veículo para beneficio próprio). Portanto, não podem ser causa de aplicabilidade das sanções de multa civil e da suspensão dos direitos políticos, pelo período mínimo de 3 (três) anos. Entretanto, é obvio que os atos cometidos pelo réu são absolutamente incompatíveis com a função que exercia, e denigrem a imagem do departamento de polícia. No entanto, como pontualmente afirmado pelo douto Juiz ' $a$ quo', as demais sanções como multa civil e suspensão dos direitos políticos, pelo período mínimo de 3 (três) anos, não são aplicáveis ao caso, in verbis:

'Saliente-se não ter havido dano no sentido econômico, daí porque não há cogitar em ressarcimento integral.

Ainda, os atos não possuem cunho político e nem estão relacionados com tal atividade. Logo, a suspensão dos direito políticos não é medida hábil e adequada. 
Admitir-se uma proibição geral e irrestrita, a partir da mera transcrição da pena em abstrato prevista na lei, e sem cogitação acerca do caso concreto e da infração a reprimir, seria impor um castigo arbitrário e aleatório.

Por isso, é inaceitável a prática - por configurar arbitrariedade, atentatória ao dever de proporcionalidade - de mera cópia da expressão legal "proibição de (...) receber benefícios ou incentivos fiscais ou creditícios" e seu translado, acriticamente, para o corpo de sentença. Isto é inadmissível sem que se justifique a pertinência da proibição com o caso concreto e se especifique, afinal, quais serão os benefícios ou incentivos proibidos.

Exige algum empenho refletir acerca da pertinência da pena de restrição do acesso a incentivos ou benefícios com o ato de improbidade apurado, mas o preço da reflexão é módico se comparado ao ônus da injustiça que seria permitir que a pena por improbidade, afinal, se convertesse em um castigo aleatório.

De resto, a lista de benefícios ou incentivos fiscais ou creditícios existentes em qualquer das esferas da federação é vasta. ${ }^{11}$ Seria manifestamente incongruente com o dever

\footnotetext{
A imposição de multa, por sua vez, também não é proporcional e nem razoável, mesmo porque o réu não é pessoa de expressivos recursos econômicos, inclusive tendo pleiteado o benefício da assistência judiciária gratuita.

De igual forma, no que tange a proibição de contratar com o Poder Público ou receber benefícios ou incentivos fiscais ou creditícios, pois nada há nos autos que demonstre ter o réu qualquer relação com esses tipos de atividades ou que seja sócio de alguma pessoa jurídica.

Em suma, a penalidade mais eficaz, proporcional e razoável é, sem dúvida, a perda da função pública, eis que os atos praticados pelo réu são absolutamente incompatíveis com tal função"'. STJ, AgRg no AREsp 367.631-PR, rel. Ministro BENEDITO GONÇALVES, Primeira Turma, j. em 1.10.2015, DJe. 7.10.2015.

${ }^{11}$ Só no âmbito federal - sem falar nos estaduais, distrital e municipais - a lista de benefícios do tipo "creditícios e financeiros" é enorme. Para se ter uma ideia dessa lista, basta consultar o Demonstrativo de Benefícios Financeiros e Creditícios - 2014 publicado pelo Ministério da Fazenda (BRASIL, Ministério da Fazenda - MF, Secretaria de Política Econômica - SPE, abril de 2015). Esse documento esclarece que, embora não haja conceitos internacionalmente pacificados, o art. $2^{\circ}$ da Portaria MF n ${ }^{\circ} 379$, de 13 de novembro de 2006, apresenta conceitos com os quais tem trabalhado a Secretaria de Política Econômica do Ministério da Fazenda.

Assim, nos termos da portaria, "benefícios ou subsídios creditícios são gastos decorrentes de programas oficiais de crédito, operacionalizados por meio de fundos ou programas, à taxa de juros inferior ao custo de captação do Governo Federal". São exemplos - citados no próprio demonstrativo - os benefícios concedidos com recursos dos Fundos Constitucionais de Financiamento (FNO, FNE. FCO), bem como do Fundo da Marinha Mercante (FMM).

Ainda nos termos da mesma portaria deve-se considerar "benefícios ou subsídios financeiros, os desembolsos efetivos realizados por meio das equalizações de juros e preços, bem como a assunção das dívidas decorrentes de saldos de obrigações de responsabilidade do Tesouro Nacional, cujos valores constam do orçamento da União". São exemplos - também citados no demonstrativo - os desembolsos do governo com o Programa de Sustentação do Investimento (PSI) e o Programa de Apoio ao Setor Sucroalcooleiro (PASS), feitos por meio do pagamento de subvenções econômicas para fins de equalização de juros. Já os desembolsos com a Política de Garantia de Preços Mínimos (PGPM) e a Subvenção a Consumidores de Energia Elétrica da Subclasse Baixa Renda são exemplos de benefícios concedidos para a equalização de preços. Finalmente, os recursos do Fundo de Compensação das Variações Salariais (FCVS) servem à concessão de benefícios decorrentes da assunção de dívidas.
} 
de proporcionalidade impor a alguém, como se fora uma panaceia de reprimenda, a vedação em bloco de acesso a todo e qualquer benefício ou incentivo fiscal ou creditício, independentemente da infração que tenha cometido.

No campo doutrinário, aliás, consoante relata Daniel Amorim Assumpção NEVES, é comum a distinção, por exemplo, entre benefícios ou incentivos outorgados em caráter geral e os concedidos em caráter individual, para sustentar-se, então, que a proibição de recebimento prevista na Lei de Improbidade só pode alcançar estes últimos; não alcançando os ditos gerais (ou incondicionais), dirigidos a um grupo, classe ou categoria de pessoas, sem a característica da pessoalidade na concessão. ${ }^{12}$ Destaque-se, nesse sentido, o entendimento de José Roberto PIMENTA OLIVEIRA, para quem, entre as isenções tributárias, por exemplo, apenas as de caráter individual podem ser apanhadas pela proibição prevista no art. 12 da Lei de Improbidade. ${ }^{13}$ São entendimentos doutrinários que, por si sós, põem em xeque a ideia rasa de que a proibição legal em comento necessariamente alcançaria quaisquer benefícios ou incentivos fiscais ou creditícios.

Tome-se como exemplo o sujeito que seja proprietário de imóvel tombado pelos órgãos de defesa do patrimônio histórico e tenha assumido todas as responsabilidades pela sua conservação. A municipalidade lhe concedeu (com base em lei própria para todos os que se encontrem em situação semelhante) isenção do IPTU atinente ao imóvel, a título de incentivo à conservação do patrimônio imobiliário de interesse histórico. Suponha-se, então, que o sujeito, envolvido em atividades empresariais na indústria farmacêutica - sem qualquer ligação, pois, com a questão do patrimônio histórico - venha a sofrer uma condenação judicial por ato de improbidade administrativa, pela qual se lhe queira impor alguma proibição de obter benefícios e incentivos fiscais ou creditícios. Pergunta-se: faria algum sentido que a

12 Confira-se Daniel Amorim Assumpção NEVES e Rafael Carvalho Rezende OLIVERA, Manual de improbidade administrativa, Rio de Janeiro, Forense; São Paulo, Método, 2012, p. 225.

${ }^{13}$ Nos dizeres de José Roberto PIMENTA OLIVEIRA: “.... sanção de proibição incide apenas sobre as isenções outorgadas em caráter individual (art. 179 do CTN), não alcançando as sanções concedidas em caráter geral. Portanto, apenas a aptidão de beneficiar-se de isenções condicionais é afetada pelo ato sancionatório, independentemente de tratar-se de isenção transitória ou permanente". Segundo o autor, o mesmo raciocínio seria aplicável aos demais benefícios fiscais outorgáveis em caráter individual: "O impedimento de receber benefícios fiscais implica na impossibilidade da pessoa física ou jurídica condenada, enquanto contribuinte, ser beneficiária, nos termos da legislação aplicável, de moratória outorgada em caráter individual (art. 153 CTN) como causa de suspensão do crédito tributário (art. 151, I CTN); de parcelamento, em idêntica situação (art. 151, VI c/c 155-A CTN); de remissão como causa legal extintiva do crédito tributário (art. 156, IV c/c art. 172 CTN); de isenção como causa excludente do crédito tributário, outorgada em caráter individual (art. 175, I c/c art. 179 CTN); de anistia, também como forma de exclusão do crédito tributário, outorgada em caráter individual (art. 175 , II c/c art. 182 CTN)". Improbidade Administrativa e sua autonomia constitucional, Belo Horizonte, Fórum, 2009, pp. 322-3. 
condenação vedasse o prosseguimento da isenção fiscal de IPTU como contrapartida da preservação do imóvel tombado?

A resposta é, evidentemente, negativa. Não pretende a Lei 8.429/92 - nem poderia têlo feito, pois seria inconstitucional - servir de instrumento para a distribuição de castigos aleatórios a sujeitos condenados por improbidade. No exemplo, cassar a isenção do IPTU (a despeito, aliás, de permanecer o sujeito obrigado a conservar o seu imóvel tombado) como "pena" pela prática de ato de improbidade em nada relacionado ao tema seria, afinal, uma punição absolutamente desconectada da infração cometida.

Outro exemplo que faz pensar: o mesmo sujeito deveria então, devido à sua condenação por improbidade no ramo farmacêutico, ser banido do acesso ao "cheque especial" (um benefício creditício, sem dúvida) em sua conta corrente em banco público? Ora, pelas mesmas razões apontadas no exemplo anterior, a "pena" aqui ventilada seria ilícita, por aleatória.

Ainda outro exemplo: suponha-se que o mesmo cidadão, apenado por improbidade nos exatos moldes dos exemplos anteriores, tenha, com base na Lei Rouanet (lei 8.313, de 23 de dezembro de 1991), destinado parcela de seu Imposto sobre a Renda (IR) ao apoio a ações culturais, obtendo em troca a possibilidade de deduzir do IR devido as quantias efetivamente despendidas naquelas ações, nos termos da lei. Pergunta-se: com a sua proibição do acesso a benefícios e incentivos fiscais, em razão da improbidade, terá sido este cidadão também proibido de continuar a fruir o benefício da dedução tributária previsto na Lei Rouanet? É óbvio que não, pela absoluta impertinência desta proibição com a infração de improbidade.

Enfim, este conjunto de exemplos é suficiente para suscitar uma questão de fundo, de suma importância: por acaso quer a Lei de Improbidade, com a sua previsão da pena de proibição de receber certos benefícios ou incentivos fiscais ou creditícios (art. 12), punir também a conservação do patrimônio histórico brasileiro, a cultura, ou ainda castigar aleatoriamente alguém? Quer ela banir o apenado do acesso a todos os benefícios e incentivos ofertáveis pelo Poder Público (leis de isenção de IPTU, benefícios da Lei Rouanet, acesso ao benefício creditício do "cheque especial" ou do cartão de crédito, entre centenas de outros), ainda que não guardem a mais remota relação com o ato ímprobo reprovado?

Parece evidente que a lei não pretendeu esse exagero. Daí o dever de o juiz, ao constatar a pertinência da aplicação da pena de proibição de receber benefícios ou incentivos 
fiscais do Poder Público em um caso concreto, especificar quais benefícios ou incentivos ficarão temporariamente proscritos para o interessado. ${ }^{14}$

Este dever de especificação da pena, pelo magistrado, nada mais é do que uma consequência necessária da postura, cada vez mais prestigiada pela jurisprudência do STJ, de levar-se a sério o dever de proporcionalidade na estipulação das sanções por improbidade.

\section{2. É ILEGAL SUPRIMIR BENEFÍCIOS E INCENTIVOS FISCAIS OU CREDITÍCIOS SEM RELAÇÃO COM O ATO DE IMPROBIDADE E COM O ENTE ESTATAL PREJUDICADO}

É exigência da proporcionalidade que a sanção seja calibrada de acordo com a infração. E calibrar - embora muitas vezes se suponha que seja só uma questão de gravidade da infração (leve, média ou alta), a gerar sanção de peso correspondente - é, como vimos, também uma questão de pertinência lógica do conteúdo da sanção com o objeto da infração. É esta necessária pertinência entre sanção e infração que faz com que, na prática, distintos aspectos da infração devam ser analisados, para que então possam refletir na aplicação de sanção condizente.

Resulta desta necessária pertinência lógica, p.ex., que não caiba apenar com restrição de abrangência nacional o responsável por ato de improbidade cujos danos tenham se revelado circunscritos ao âmbito municipal, sem qualquer transcendência relevante.

No caso, por exemplo, de infração e prejuízo decorrentes de relação contratual de empresa com um pequeno Município, em virtude da proporcionalidade, a proibição a ser imposta, de obter benefícios ou incentivos fiscais ou creditícios, somente pode dizer respeito àqueles obteníveis junto ao próprio Município envolvido. Não pode alcançar benefícios ou incentivos de outros Poderes Públicos - sejam entes da federação, sejam entidades de suas administrações indiretas - que não o Município em questão. Não teria pertinência com a infração - e atentaria contra a proporcionalidade - a aplicação de restrição de abrangência

\footnotetext{
${ }^{14}$ Vale frisar que, entendendo o juiz pela impertinência da imposição da pena de proibição de receber benefícios ou incentivos tendo em vista o caso concreto, ainda assim será necessário avaliar o cabimento de outras sanções (ressarcimento do dano, multa, perda de função pública e suspensão de direitos políticos).

Afinal, como já visto, as sanções do art. 12 da Lei $8.429 / 92$ não são necessariamente cumulativas e o ato de improbidade poderá ser apenado por ao menos uma das outras sanções. Certo é, conforme decisão do STJ (REsp 980.706-RS, rel. Ministro LUIZ FUX, Primeira Turma, j. em 3.2.2011, DJe 23.2.2011), que ao magistrado é permitido aplicar somente a pena que verifique ser condizente com a repressão e a prevenção da improbidade.
} 
nacional ou mesmo regional, que seria castigo aleatório, dissonante do caráter bem circunscrito à localidade da infração.

A Lei de Improbidade, aliás, no art. 12, incisos I, II e III, faz referência apenas a "Poder Público", no singular (isto é, à proibição de dele, "Poder Público", se receberem benefícios ou incentivos fiscais ou creditícios). Não diz que a proibição alcance todos os Poderes Públicos, no plural: União, Estados, Distrito Federal e Municípios. Na ausência dessa especificação, não se pode, por via de interpretação, pretender ampliar o alcance da sanção, inflando-a para além do autorizado pela lei. ${ }^{15}$

A propósito, esta leitura é consentânea com a mais recente e abalizada orientação jurisprudencial do STJ. Há três importantes precedentes do tribunal dignos de nota em matéria de observância do dever de proporcionalidade na aplicação das penas por improbidade administrativa, particularmente daquelas de proibição de contratar com o Poder Público ou de receber benefícios ou incentivos físcais ou creditícios (art. 12 da Lei de Improbidade Administrativa).

Neles o Tribunal Superior fixou a diretriz segundo a qual as penas de proibição de contratar ou de receber benefícios ou incentivos fiscais ou creditícios devem guardar conexão com o ato de improbidade verificado no caso concreto, não indo além do âmbito territorial em que verificado o ato e no qual tenha se circunscrito o dano causado.

\footnotetext{
${ }^{15}$ Um dos autores deste estudo já manifestou opinião sobre a correta interpretação das leis administrativas em matéria sancionatória: "Silente a lei quanto à abrangência das sanções, deve-se interpretá-la restritiva, não ampliativamente, donde a necessidade de aceitar, como correta, a interpretação segundo a qual o impedimento de licitar só existe em relação à esfera administrativa que tenha imposto a sanção. Adotar posição oposta significaria obrigar alguém a deixar de fazer algo sem lei específica que o determine, em confronto com o princípio da legalidade, o qual, especificamente em matéria sancionatória, deve ser entendido como de estrita legalidade". Carlos Ari SUNDFELD, Licitação e contrato administrativo - De acordo com as Leis 8.666/1993 e 8.883/1994, $2^{\mathrm{a}}$ ed., São Paulo, Malheiros, 1995, p. 117.

De sua parte, José Nilo de CASTRO opinou em defesa de interpretação estrita da proibição de contratar com o Poder Público constante da Lei de Improbidade Administrativa, concluindo: “...impera aqui, na hipótese, necessidade de interpretarem-se restritivamente os comandos do art. 12, III, da Lei ${ }^{\circ}$ 8.429/92... Não há, portanto, que se falar em aplicação automática da pena de proibição de contratar com o Poder Público senão aquele no qual ocorreu o ato de improbidade administrativa".

$\mathrm{O}$ autor ainda lembra o exemplo do art. $7^{\circ}$ da Lei do Pregão (Lei $\mathrm{n}^{\circ} 10.520 / 2002$ ), que prevê sanção de impedimento de “...licitar e contratar com a União, Estados, Distrito Federal e Municípios...", deixando clara a intenção do legislador de estipular uma sanção de amplo alcance. Não é o que faz a Lei de Improbidade, avalia José Nilo de CASTRO. "Parecer - Proibição de contratar com o Poder Público: extensão da pena do art. 12, III, da Lei de Improbidade Administrativa", in: Revista Brasileira de Direito Municipal - RBDM, Belo Horizonte, Fórum, a. 9, n. ${ }^{\circ} 29$, jul./set., 2008, pp. 141-53.
} 
Em um dos julgados ${ }^{16}$ apontavam-se ilegalidades em aditivos de contrato entre duas empreiteiras de grande porte e a LIMPURB, empresa de limpeza pública do Município de São Paulo. A sentença, mantida pelo Tribunal de Justiça do Estado de São Paulo (TJSP), impôs às empreiteiras as sanções de proibição de contratar com o Poder Público e de receber benefícios ou incentivos fiscais ou creditícios pelo prazo de 5 anos. O STJ, analisando a extensão do dano causado pelas irregularidades apontadas e o proveito patrimonial obtido por cada uma das empresas, calibrou a extensão territorial e os limites das sanções, invocando como fundamentos os princípios da legalidade estrita e da proporcionalidade. Para uma das empresas, que participou em menor grau das irregularidades apontadas, a Ministra Eliana Calmon entendeu que:

“...é natural que se module o efeito da condenação quanto à sanção administrativa, em nome do princípio da legalidade estrita. Dentro desse quadro normativo entendo que a proibição de contratar com o poder público deve se restringir ao âmbito do Município de São Paulo, mas apenas em relação aos certames promovidos pela LIMPURB, empresa que veio a sofrer o prejuízo. Quanto ao impedimento de obter a empresa benefícios e incentivos, entendo que a restrição deve limitar-se ao Município de São Paulo, ao qual pertence a empresa atingida pelo prejuízo". Grifos acrescentados.

No mesmo julgado, a "calibração" dos efeitos da condenação e da sua extensão territorial quanto à outra empresa demonstra, ainda mais, a inclinação do tribunal para a interpretação da Lei de Improbidade calcada na estrita legalidade e na proporcionalidade, de modo a ajustar o conteúdo das sanções ao objeto das infrações correspondentes. Assim, mesmo concluindo que o recurso interposto tinha a pretensão de rediscutir a matéria, algo que não seria permitido em embargos de declaração, a Ministra Eliana Calmon o aceitou, ponderando sobre a importância de assegurar adequada conexão entre infração e sanção, julgando-as ambas circunscritas ao âmbito do Município:

"Embora consciente da limitação dos aclaratórios, bem assim do próprio recurso
especial, não posso deixar de sensibilizar-me com o rigor formal da atividade
sancionatória da administração, a qual, como disse acima obedece ao princípio da
legalidade estrita. Em nome desse princípio fujo das limitações eminentemente
processuais para adequar o julgado aos ditames da lei especial. Examinando a
querela no ponto da sanção, pelo princípio da proporcionalidade, não me
parece razoável que uma empresa como a [...], mesmo tendo cometido grave
infração contratual que a torna ímproba, venha a ter decretada sentença de morte.

${ }^{16}$ STJ, EDcl no REsp n. ${ }^{\circ}$ 1.021.851-SP, relatora Ministra ELIANA CALMON, Segunda Turma, j. em 23.6.2009, DJe de 6.8.2009. 
Sim, porque nenhuma empresa de grande porte resistirá a ficar por cinco anos sem contratar com o serviço público em toda e qualquer unidade da Federação. Daí a necessidade de delimitar-se a reprimenda administrativa para situá-la dentro dos limites do Município de São Paulo, estabelecendo-se a sanção de proibição de contratar com o serviço público municipal, dentro da cidade de São Paulo, o que deixa livre a empresa para contratar com outros municípios, inclusive os que formam a chamada Grande São Paulo". Grifos acrescentados.

Outro caso analisado pelo STJ tratou da contratação direta, sem licitação, de empresa para o fornecimento de passagens e fretamentos de ônibus pelo Estado de Rondônia. Os procedimentos foram considerados ilegais pelo Tribunal de Justiça de Rondônia (TJRO) e a empresa, que também atua em todo o território nacional como concessionária de serviço público, sofreu a pena de proibição de contratar com o Poder Público e de receber incentivos por um período de 5 anos. Muito naturalmente, o STJ restringiu a proibição de contratar aos limites do Estado de Rondônia, lesado com o ato de improbidade. Para o Ministro Teori Albino Zavascki:

\footnotetext{
"Impedir que os demandados, especialmente a empresa de ônibus, possam contratar com outros órgãos da Administração Pública (da União, de outros Estados ou de Municípios), representaria pena desproporcional, incompatível com o princípio da razoabilidade com a qual deve ser ajustada". ${ }^{17}$
}

Logo, o STJ também nesse caso calibrou a sanção à infração cometida, circunscrevendo a restrição à administração pública que teria sido lesada.

Uma terceira decisão do STJ, mais recente, cita um desses precedentes justamente para afirmar que "a jurisprudência desta Corte Superior vem entendendo ser possível a modulação da citada penalidade diante dos elementos do caso concreto". ${ }^{18}$ Trata-se de recente acórdão em que o STJ examinou a declaração de nulidade de contratação direta, pelo Município de Eldorado Paulista/SP, de serviços de recuperação de rodovias, bem como a extensão da pena de proibição de contratar com o Poder Público imposta à empresa responsável (sem menção, todavia, à pena de proibição de receber benefícios ou incentivos fiscais). Confira-se excerto do julgado:

\footnotetext{
${ }^{17}$ REsp 1.003.179-RO, rel. Ministro TEORI ALBINO ZAVASCKI, Primeira Turma, j. em 5.8.2008, DJe de 18.8.2008.

${ }^{18}$ REsp n. ${ }^{\circ}$ 1.188.289-SP, rel. Ministro HERMAN BENJAMIN. Segunda Turma, j. em 14.8.2012, DJe de 13.12.2013.
} 
“Com efeito, a modulação da pena de proibição de contratar pode ser feita por elementos do caso concreto, como a ocorrência de: gravidade da conduta, possibilidade de sua repetição nas demais esferas da Administração, interesse público de caráter nacional. Sobre ser viável modular a citada a citada penalidade: EDcl no REsp 1.021.851/SP, Rel. Ministra Eliana Calmon, Segunda Turma, DJe 6.8.2009. Neste feito e tendo em vista os critérios acima, os elementos assentados pelo Tribunal de origem indicam exarcebação da penalidade imposta, de forma que é de rigor a modulação da pena de proibição de contratar com a Administração Pública para restringi-la à esfera municipal”.

A citada "modulação" da pena, feita para restringi-la à esfera municipal, é uma adequação sua aos elementos do caso concreto, considerando-se que a infração ocorreu no âmbito de relação jurídica pontual com o citado Município, sem repercussão de danos para outras esferas da federação. Reafirmou-se, pois, a orientação jurisprudencial daquele tribunal.

Existe, portanto, clara orientação do STJ a exigir a observância de relação de conexão ou pertinência lógica do conteúdo da pena com o objeto da infração (improbidade) cometida, particularmente das aludidas penas de proibição de contratar com o Poder Público e dele receber benefícios ou incentivos fiscais ou creditícios. ${ }^{19}$

\footnotetext{
19 Registre-se que existem algumas decisões em contrário de tribunais inferiores, as quais preferiram uma interpretação ampliativa do art. 12 da Lei de Improbidade Administrativa - no sentido de que a pena ali prevista alcançaria todos os órgãos e esferas de governo - enxergando-se na expressão "Poder Público" (no singular) uma alusão necessária a todos os Poderes Públicos existentes no Brasil (no plural), sem se esclarecer, contudo, como o singular da lei poderia ser transformado em um plural por seus aplicadores.

É o caso, p. ex., deste julgado do TJSP: “Já em relação ao âmbito de aplicação da pena de proibição de contratar com o poder público, convém considerar o que dito expressamente pela Lei, segundo a qual, no caso de ofensa do art. 10, da Lei $n^{\circ}$ 8.429/92, possível a aplicação desta penalidade de 'proibição de contratar com o Poder Público’ (art. 12, II). Desta forma, tanto os entes Municipais, como Estaduais e o Federal são considerados para esta finalidade como Poder Público, não havendo como destacar deste termo a limitação imaginada pela corré [...], a apenas ao ente Municipal que sofrera o prejuízo". TJSP, EDcl n. ${ }^{\circ}$ 0005274-82.2010.8.26.0037/50000, 9a Câmara de Direito Público, rel. Desembargador Rebouças de Carvalho, j. em 9.4.2014.

Esse tipo de entendimento, contudo, enfrenta contestação não apenas no STJ, como já assinalado, mas também na própria doutrina. Confira-se Marcia PELEGRINI, que bem coloca o significado da expressão "Poder Público" na norma sancionadora constante da Lei de Improbidade: "a extensão territorial da proibição de contratar com Poder Público, segundo nosso entendimento, também é aspecto a ser estabelecido na decisão judicial, ou seja, quando aplicada a penalidade, deverá o Juiz competente sopesar as consequências e fixar a extensão territorial da proibição, levando em consideração os aspectos já acima relatados". E explica: "existem entendimentos, baseados precipuamente na interpretação literal do texto legal considerando-se o conteúdo semântico da expressão 'Poder Público', no sentido que a abrangência é o território nacional em toda e qualquer situação. A nós parece que dessa forma o caráter draconiano da lei prepondera em detrimento da razoabilidade e da justiça. Como já asseveramos, não há como o julgador ignorar a gravidade do caso concreto, a presença do dolo, da fraude, para aplicar a pena. Esta deve incidir na medida da estrita necessidade para atendimento da finalidade da lei". "Lei de Improbidade Administrativa - Extensão Territorial dos Efeitos da Pena de Proibição de Contratar
} 
Que tipo de conexão? Entre os elementos indicativos de uma conexão, o STJ tem destacado o da extensão do dano causado e, particularmente, o de qual foi o ente lesado pelo ato de improbidade, de modo a limitar a reprimenda de restrição a novas relações jurídicas com aquele específico ente público (sem ampliá-la, pois, aos demais entes da federação).

É de se frisar que, especificamente quanto à proibição que ora interessa - que é a de receber benefícios ou incentivos fiscais ou creditícios - a diretriz jurisprudencial é explícita no sentido de que ela deva se limitar àqueles obteníveis junto ao Município lesionado, quando o dano não tenha transcendido a esfera municipal.

Também é de se salientar, dentre os precedentes, a clara repulsa a emprestar-se repercussão nacional a uma sanção decorrente de infração restrita ao âmbito local. Nos enfáticos dizeres de um dos citados precedentes, uma infração de repercussão meramente municipal não pode gerar uma "sentença de morte" da apenada, pela imposição a ela de uma proibição de contratar e de receber benefícios ou incentivos que alcance todas as esferas da federação em que atue, em todo o território nacional.

\section{INVIABILIDADE DE CONDENAÇÃO AUTOMÁTICA DAS PESSOAS JURÍDICAS DE QUE O APENADO SEJA SÓCIO MAJORITÁRIO}

Em norma correta e justa, a Lei da Improbidade teve a prudência de impedir que alguém, apenado judicialmente com a proibição de contratar ou de receber incentivos públicos, venha a usar simples artifício formal para esquivar-se dos efeitos das sanções. $\mathrm{O}$ apenado está proibido de estabelecer tais relações também quando o faça pela intermediação de pessoa jurídica de que seja controlador. Em suma, o sujeito proibido de contratar não pode ser o executante real e o destinatário final dos pagamentos de um contrato público celebrado por empresa sob seu controle, de nada valendo o argumento, puramente formal, de que sua relação contratual não é com o Estado, mas com empresa privada. O que conta não é a aparência, mas a substância: se o executante e destinatário das prestações contratadas é o próprio apenado, e a empresa simples intermediária formal, os efeitos da sanção têm obviamente de valer.

Apesar de a linguagem da lei poder dar ensejo a alguma dúvida no leitor desatento ao genericamente prever a proibição de o punido receber benefícios fiscais ou creditícios

com o Poder Público". In: BDA - Boletim de Direito Administrativo, NDJ, ano 25, n. ${ }^{\circ}$ 6, junho de 2009, p. 676 (grifo acrescentado). 
“direta ou indiretamente, ainda que por intermédio de pessoa jurídica da qual seja sócio majoritário" - é evidente que a norma não autoriza que se inclua na condenação, de modo automático e sem processo, as pessoas jurídicas de que a pessoa física apenada seja sócia majoritária. E isso pela razão de que, nas situações normais, e muito especialmente nos grandes grupos empresariais, a empresa de que se é acionista tem suas atividades, seu patrimônio, seu pessoal, sua vida própria e efetiva, sendo errado presumi-la como mera cobertura formal interposta entre os clientes da empresa e algum de seus acionistas.

A situação é ainda mais clara nas sanções contra pessoas físicas. O médico que, por improbidade, é condenado a não contratar com o Estado, não pode continuar atendendo pacientes da rede pública e emitir as faturas em nome de clínica médica (pessoa jurídica) de que seja titular. Mas, se o mesmo médico for o acionista de um grande banco, por certo que esta instituição não ficará suspensa do mercado público só por conta da condenação de seu acionista pessoa física. Qual a razão? É simples e evidente: nos exemplos citados, a clínica médica é sim intermediária formal entre o cliente e o médico (que é o efetivo prestador e o remunerado, como pessoa física), enquanto o grande banco por certo não é simples intermediário entre o cliente e a pessoa física de seu acionista, que não se envolve pessoalmente na execução das prestações respectivas e não é remunerado especificamente por elas.

Destaque-se isto: é o texto da lei que exige a presença da figura da intermediação (de contrato, de benefício ou creditício), não se contentando com a relação de controle societário.

Se não fosse assim, isto é, se houvesse condenação automática da empresa no processo de que seu acionista pessoa física fosse réu, a contaminação atingiria pessoas que nada teriam a ver com o ilícito e que não teriam sido parte no processo judicial. A pena acabaria aplicada para além da pessoa do infrator e réu - como se fosse uma pena coletiva, difusa, aleatória. Operar-se-ia uma transferência automática da pena, sem nenhum sentido e em flagrante atentado à Constituição Federal.

Evidentemente, não é esta condenação automática de outra pessoa, alheia ao processo, o que pretendeu a norma legal. A expressão da lei ("ainda que por intermédio de pessoa jurídica da qual seja sócio majoritário") deve ser lida nos seus exatos termos, sendo vedada, por inconstitucional, qualquer leitura ampliativa e distorcida que admita transferências automáticas de penalidades. 
Aliás, por meio da ADI nº 4.295, ajuizada pelo Partido da Mobilização Nacional (PMN) no Supremo Tribunal Federal (STF), propôs-se justamente a discussão sobre a constitucionalidade das partes finais dos incisos I, II e III do art. 12 da Lei de Improbidade, e isto com base no princípio da "incomunicabilidade das penas".

A tese da inconstitucionalidade encontra amparo doutrinário em autores que vislumbram nessas disposições legais verdadeiro atentado quer ao aludido preceito de "incomunicabilidade" ou "intransferibilidade das penas" $\left(\mathrm{CF}\right.$, art. $\left.5^{\circ}, \mathrm{XLV}\right),{ }^{20}$ quer ao princípio da "individualização" ou "personalização da pena" (CF, art. $\left.5^{\circ}, \mathrm{XLVI}\right){ }^{21}$

Em verdade, o que precisa sim ser afastada, por inconstitucional, é a equivocada interpretação de que essas normas teriam autorizado a extensão automática a outrem da pena aplicada a um agente cuja conduta tenha sido declarada como ímproba.

É viável, e ajustada ao texto da lei, a interpretação que preserve, em conformidade com a Constituição, a pessoalidade das penas e, assim, a norma estampada no art. 12 da Lei de Improbidade. A propósito do sentido desta norma da Lei de Improbidade já se observou, em outro estudo: “A lei é clara quanto a isso: a sanção é sempre pessoal (...); não existem sanções difusas ou coletivas, que alcancem outrem em virtude de simples vínculos de capital, não como consequência da prática pessoal de infrações". ${ }^{22}$

A única leitura admissível da lei é realmente a que a considere nos seus exatos termos, isto é, no sentido de que a extensão da pena só é possível, à luz das partes finais dos incisos I,

\footnotetext{
${ }^{20}$ Marcelo FIGUEIREDO: “A lei em foco é radical, ao atingir com uma só penada a pessoa física e a jurídica, sem qualquer consideração a respeito de eventual conexão entre ambas as figuras - pessoa física e jurídica. Tal como vazado, o dispositivo se nos afigura inconstitucional, por ausência de proporcionalidade.

(...)

Deveras, é princípio constitucional expresso a norma do art. $5^{\circ}, \mathrm{XLV}$, aquele que contempla a intransferibilidade da pena. Do mesmo modo, o inciso seguinte (art. $5^{\circ}$, XLVI) contempla a individualização da pena como princípio constitucional. Ambas as regras constitucionais fornecem ao intérprete o vetor segundo o qual não poderá a pena ultrapassar a pessoa (singular) do condenado e, ainda, que a mesma se contenha nele. Ora, a citada lei anotada contempla com elastério regra violadora da Constituição Federal. Se a pena somente deve recair sobre quem praticou o ilícito (não importa de que categoria, se penal, administrativo, civil, etc.), segue-se que há interdição para 'extensão' da pena à pessoa jurídica”. Probidade Administrativa - Comentários à Lei 8.429/92 e Legislação Complementar, 5a . ed., São Paulo, Malheiros, 2004, pp. 151 e 153.

${ }^{21}$ Marçal JUSTEN FILHO: "Os dispositivos são parcialmente inconstitucionais quando estendem a apenação a pessoa jurídicas das quais o condenado seja sócio majoritário, pois há infração do princípio constitucional da personalidade das penas (art. $5^{\circ}$, XLV, da CF/88)." Marçal JUSTEN FILHO, Curso de Direito Administrativo, $10^{\mathrm{a}}$ ed., São Paulo, Revista dos Tribunais, p. 1.102, 2014.

${ }^{22}$ Carlos Ari SUNDFELD e Jacintho ARRUDA CÂMARA, "A proibição de contratar com o Poder Público e seus efeitos sobre os grupos empresariais", in: Carlos Ari Sundfeld e Guilherme Jardim Jurksaitis (orgs.), Contratos públicos e direito administrativo, São Paulo, Malheiros, Sociedade Brasileira de Direito Público e Direito GV, 2015, p. 201.
} 
II e III do art. 12, naquelas hipóteses em que uma pessoa jurídica venha a ser constituída ou utilizada como veículo para o cometimento de fraude ou quando se constate abuso da personalidade jurídica. Aí, sim, poderá se operar a extensão da pena, sem atentado à Constituição. ${ }^{23}{ }^{24}$

No mesmo estudo anterior se procurou examinar, particularmente, a viabilidade jurídica de extensão, ou não, da sanção restritiva da contratação administrativa na Lei de Improbidade, aplicada a uma pessoa jurídica, a outra pessoa jurídica sobre a qual tenha influência. Concluiu-se no sentido da sua inviabilidade, exceto em casos de abuso da personalidade jurídica ou fraude pura e simples do sistema punitivo legal, caracterizáveis, entre outros indícios relevantes, pela semelhança de objetos sociais entre as empresas (o da apenada e o da empresa fraudulenta) e pelo momento de criação da empresa fraudulenta (posterior à aplicação da pena). ${ }^{25}$

A mesma ratio se aplica ao caso de pessoa física apenada com proibição de contratar e receber benefícios ou incentivos fiscais e creditícios, nos termos da Lei de Improbidade. Também não se pode admitir extensão da pena aplicada à pessoa física a outrem, isto é, a empresa de que seja sócio majoritário, em virtude de simples vínculo de capital. Uma extensão somente seria cogitável se fosse o caso de pequena empresa, personalíssima, que servisse de simples intermediária formal entre o apenado pessoa física e o contratante. Mas não sendo esse o caso, não podendo a empresa ser confundida com a pessoa física de seu acionista ou sócio, não há sequer em tese espaço para análise de eventual constituição ou utilização abusiva ou fraudulenta, com o fito de burlar a pena aplicada.

\footnotetext{
${ }^{23}$ Fábio MEDINA OSÓRIO: "Atingem-se, portanto, as empresas eventualmente constituídas como 'testas de ferro' dos agentes contemplados com proibições de contratar com a Administração Pública ou receber benefícios ou incentivos fiscais ou creditícios. O problema será resolvido no terreno probatório". Improbidade Administrativa-Observações sobre a Lei 8.429/1992, 2a ed., Porto Alegre, Síntese, 1998, p. 261.

${ }^{24}$ Marcelo FIGUEIREDO: "Será preciso demonstrar por todos os meios em Direito permitidos que a empresa à qual pertence não se prestou de mera "fachada" para os objetivos vedados pela norma comentada". E continua: "Em suma, a personalidade jurídica do responsável (pessoa jurídica) por infração à probidade administrativa poderia ser descaracterizada quando houvesse abuso de direito, excesso de poder ou infração à lei." E conclui: "Quer-nos parecer, portanto, que deva existir uma individualização da pena, e não sua superposição". Probidade Administrativa - Comentários à Lei 8.429/92 e Legislação Complementar, 5a. ed., São Paulo, Malheiros, 2004, pp. 151-3.

${ }^{25}$ Observou-se: “A lei proíbe a 'contratação indireta' da pessoa jurídica punida. Seria o caso de a contratação ser formalmente realizada por meio de interposta pessoa mas, de fato, a entidade punida ser a verdadeira executora e beneficiária do contrato". Carlos Ari SUNDFELD e Jacintho ARRUDA CÂMARA, "A proibição de contratar com o Poder Público e seus efeitos sobre os grupos empresariais", in: Carlos Ari Sundfeld e Guilherme Jardim Jurksaitis (orgs.), Contratos públicos e direito administrativo, São Paulo, Malheiros, Sociedade Brasileira de Direito Público e Direito GV, 2015, p. 201.
} 
Cumpre lembrar que a criação de entes com personalidade jurídica autônoma, em Direito, tem sua razão de ser. Como já se assinalou no referido estudo, "ao se admitir a criação de novos entes dotados de personalidade jurídica, o que a legislação pretende e fomenta é a divisão de ativos e passivos, isto é, o isolamento de determinada unidade formal em relação a outros sujeitos de direitos, seus sócios, suas controladas, subsidiárias e assim por diante. A ruptura desse sistema não pode ser tomada como regra. E não é", ${ }^{26}$

A eventual desconsideração da personalidade jurídica, pela via da extensão da pena, só cabe mesmo nas apontadas circunstâncias excepcionais. ${ }^{27}$

Assim, por exemplo: se um advogado vier a praticar ato qualificado como ímprobo e, portanto, vier a sofrer a pena, enquanto pessoa física, de proibição de contratar com o Poder Público, esta proibição incluirá também a impossibilidade de ser contratado tendo como veículo a sociedade de advogados de que seja sócio. Afinal, os serviços de advocacia são prestados intuito personae e, nitidamente, constituirá abuso de personalidade jurídica, ou pura e simplesmente fraude, contratar o advogado apenado por meio da pessoa jurídica apenas para driblar a proibição (sendo o próprio advogado, naturalmente, o verdadeiro executor e beneficiário direto do contrato).

Por certo, eventuais incentivos fiscais e creditícios públicos que se apliquem às empresas integrantes de um grupo e às atividades que elas legitimamente desempenham não podem ser de modo algum confundidos com benefícios que seriam usufruíveis pessoal e individualmente pelas pessoas de seus sócios.

\footnotetext{
${ }^{26}$ Obra citada, p. 198.

${ }^{27}$ No caso desta norma da Lei 8.429/92, a extensão da proibição de receber benefícios ou incentivos, sofrida pela pessoa física, para a pessoa jurídica da qual seja sócia majoritária constitui uma espécie de "desconsideração da personalidade jurídica em sentido inverso". O fenômeno é aludido na doutrina especializada, como relata e explica André Pagani de SOUZA:

"Geralmente, a teoria da desconsideração da personalidade jurídica é invocada para responsabilizar o integrante da pessoa jurídica por dívida formalmente imputada a esta última. Porém, o inverso também é permitido: afastarse o princípio da autonomia patrimonial da pessoa física para responsabilizar a pessoa jurídica por obrigação do seu integrante. A desconsideração inversa da personalidade jurídica normalmente é invocada em casos de desvio de bens, quando o devedor transfere seus bens para uma pessoa jurídica sobre a qual detém o controle. Assim, ele continua a usufruir de tais bens, apesar de não serem formalmente de sua propriedade, mas sim da pessoa jurídica controlada". Desconsideração da personalidade jurídica: aspectos processuais, São Paulo, Saraiva, 2009, p. 61.

É de se notar, porém, que a espécie de desconsideração inversa da personalidade jurídica que se vislumbra na norma da Lei de Improbidade não resulta de desvio de bens, mas de uma eventual tentativa de burla ao sistema legal punitivo ou de uma fraude pura e simples. Devido a esta burla ou fraude afasta-se a autonomia da pessoa física punida para estender a punição à pessoa jurídica de que seja integrante (isto é, àquela pessoa utilizada como artifício para contornar a punição). De toda maneira, é certo que os pressupostos originais da aplicação da teoria - existência de abuso de personalidade ou fraude - se aplicam também quando a desconsideração é invertida.
} 
Vale notar que a fraude é um pressuposto da desconsideração da personalidade jurídica, segundo a teoria que veio a ser adotada também no Direito brasileiro. Ou seja, não se desconsidera a personalidade jurídica, para responsabilizar os seus sócios ou controladores, sem que se tenha comprovado que a pessoa jurídica foi constituída de modo abusivo ou fraudulento. No caso da pena de proibição prevista na Lei de Improbidade Administrativa, há que se operar justamente uma desconsideração da personalidade jurídica da empresa da qual o apenado seja sócio majoritário para reputar-se, então, que o benefício ou incentivo fiscal ou creditício por ela (empresa) obtido tenha como real beneficiário o sócio, pessoal e individualmente considerado. Ora, tal desconsideração só seria possível, em casos assim, mediante comprovação de que a constituição ou utilização da empresa é fraudulenta, servindo de mero veículo para burlar o sistema punitivo engendrado pela legislação. Logo, também a teoria da desconsideração de personalidade jurídica pressuporia a demonstração de alguma sorte de fraude ou abuso de personalidade para que, a final, a proibição que recai sobre a pessoa do sócio também repercuta sobre a empresa. Sem fraude ou abuso, não há que se falar em repercussão.

Mesmo para aqueles que, por excesso, quisessem enxergar na previsão da Lei de Improbidade uma "fraude presumida" - como se a lei tivesse instituído presunção de fraude pela só circunstância de uma empresa receber benefícios ou incentivos fiscais ou creditícios tendo como sócio majoritário alguém proibido de recebê-los por sentença de improbidade -, haveria de se ter a presunção como limitada e relativa (juris tantum) e não como geral e absoluta (jure et de jure). Afinal, presunção geral e absoluta instituída por lei seria equivalente a uma punição automática de terceiro, atentatória contra os princípios da pessoalidade e individualização das penas. Logo, seria uma presunção necessariamente limitada e relativa, que, como tal, admitiria demonstração em contrário, considerando-se cada operação envolvida. Assim, a questão se resolveria no terreno fático, em que a empresa cujo sócio majoritário tivesse sido apenado por improbidade poderia comprovar que a operação creditícia, por exemplo, está inserida dentro de seu campo empresarial normal (financiamento de certo empreendimento integrante de seu objeto social, por exemplo), não se destinando, assim, à fruição individual e pessoal por seu sócio, o que, se ocorresse, poderia, de fato, ser meio de fraude à condenação.

Todavia, e como já assinalado, a Lei de Improbidade não instituiu presunção nem ônus probatório para ninguém, a priori, pois não poderia compactuar com a perigosa ideia da 
comunicabilidade automática de sanções, vulneradora da lógica e de tão importantes garantias constitucionais. Se suscitada formalmente a acusação de que o agente apenado por improbidade e proibido de receber benefícios ou incentivos fiscais ou creditícios esteja, no fundo, a utilizar interposta pessoa jurídica para contornar a proibição, em seu proveito pessoal, individual, então poderá haver discussão a respeito, sob o crivo do contraditório e da ampla defesa, aplicando-se o ordinário modo de distribuição do ônus da prova (ou seja, caberá ao acusador demonstrar e comprovar a alegada fraude).

\section{REFERÊNCIAS}

BRASIL. Ministério da Fazenda. Secretaria de Política Econômica. Demonstrativo de Benefícios Financeiros e Creditícios - 2014, abril de 2015.

BRASIL. Tribunal de Justiça do Estado de São Paulo. EDcl n. ${ }^{\circ}$ 000527482.2010.8.26.0037/50000, 9a Câmara de Direito Público, rel. Desembargador Rebouças de Carvalho, j. em 9.4.2014.

BRASIL. Tribunal de Justiça do Estado do Rio Grande do Sul. Apelação Cível 70033461856, rel. Desembargador Jorge Maraschin dos Santos, j. em 15.12.2010.

BRASIL. Superior Tribunal de Justiça. AgRg no AREsp 367.631-PR, rel. Ministro BENEDITO GONÇALVES, Primeira Turma, j. em 1.10.2015, DJe. 7.10.2015.

. REsp n. ${ }^{\circ}$ 1.188.289-SP, rel. Ministro HERMAN BENJAMIN. Segunda Turma, j. em 14.8.2012, DJe de 13.12.2013.

. AgRg no REsp 1.242.939 SP, rel. Ministro HERMAN BENJAMIN, Segunda Turma, j. em 24.5.2011, DJe 30.5.2011.

DJe 23.2.2011.

REsp 980.706-RS, rel. Ministro LUIZ FUX, Primeira Turma, j. em 03.2.2011,

. REsp 1.130.198-RR, rel. Ministro LUIZ FUX, Primeira Turma, j. em 2.12.2010, DJe 15.12.2010.

EDcl no REsp n. ${ }^{\circ}$ 1.021.851-SP, rel. Ministra ELIANA CALMON, Segunda Turma, j. em 23.6.2009, DJe de 6.8.2009.

. REsp 1.003.179-RO, rel. Ministro TEORI ALBINO ZAVASCKI, Primeira Turma, j. em 5.8.2008, DJe de 18.8.2008. 
. REsp 507.574-MG, rel. Ministro TEORI ZAVASCHI, Primeira Turma, j. em 15.9.2005, DJe 8.5.2006.

CASTRO, José Nilo de. "Parecer - Proibição de contratar com o Poder Público: extensão da pena do art. 12, III, da Lei de Improbidade Administrativa". In: Revista Brasileira de Direito Municipal-RBDM, Belo Horizonte, Fórum, a. 9, n. . 29, jul./set., 2008, pp. 141-53.

FIGUEIREDO, Marcelo. Probidade Administrativa - Comentários à Lei 8.429/92 e Legislação Complementar. 5a . ed., São Paulo, Malheiros, 2004.

JUSTEN FILHO, Marçal. Curso de Direito Administrativo. 10a. ed, São Paulo, Revista dos Tribunais, 2014.

MEDINA OSÓRIO, Fábio. Improbidade Administrativa - Observações sobre a Lei 8.429/1992. 2a ed., Porto Alegre, Síntese, 1998.

NEVES, Daniel Amorim Assumpção; OLIVEIRA, Rafael Carvalho Rezende. Manual de improbidade administrativa. Rio de Janeiro, Forense; São Paulo, Método, 2012.

PELEGRINI, Márcia. "Lei de Improbidade Administrativa - Extensão Territorial dos Efeitos da Pena de Proibição de Contratar com o Poder Público". In: BDA - Boletim de Direito Administrativo, NDJ, ano 25, n. ${ }^{\circ}$ 6, junho de 2009.

PIMENTA OLIVEIRA, José Roberto. Improbidade Administrativa e sua autonomia constitucional, Belo Horizonte, Fórum, 2009.

SOUZA, André Pagani de. Desconsideração da personalidade jurídica: aspectos processuais. São Paulo, Saraiva, 2009.

SUNDFELD, Carlos Ari. Licitação e contrato administrativo - De acordo com as Leis 8.666/1993 e 8.883/1994. 2a ed., São Paulo, Malheiros, 1995.

SUNDFELD, Carlos Ari; ARRUDA CÂMARA, Jacintho. "A proibição de contratar com o Poder Público e seus efeitos sobre os grupos empresariais". In: Carlos Ari Sundfeld e Guilherme Jardim Jurksaitis (orgs.), Contratos públicos e direito administrativo, São Paulo, Malheiros, Sociedade Brasileira de Direito Público e Direito GV, 2015, pp. 189-211. 